Manuscript received: 01.10.2021

Accepted: 16.10.2021

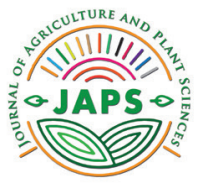

In print: ISSN 2545-4447

On line: ISSN 2545-4455

doi: https://doi.org/10.46763/JAPS21192027k

Original scientific paper

\title{
ONE FACTORIAL ANOVA IN ASSESSMENT OF GROUNDWATER QUALITY IN VULNERABLE AREA OF AGRICULTURE POLLUTION
}

\author{
Biljana Kovacevik', Sasa Mitrev', Ivan Boev², Natalija Markova Ruzdik', Blazo Boev² \\ 'Faculty of Agriculture, University "Goce Delcev", Krste Misirkov bb, 2000 Stip, Republic of North Macedonia \\ ${ }^{2}$ Faculty of Natural and Technical Sciences, University "Goce Delcev", Krste Misirkov bb, 2000 Stip, \\ Republic of North Macedonia \\ *Corresponding author: biljana.kovacevik@ugd.edu.mk
}

\begin{abstract}
Arsenic polluted groundwater was found in the Strumica region located in the south-east part of the Republic of North Macedonia where an intensive agriculture production is concentrated on the area of around $1000 \mathrm{~km}^{2}$. Out of 185 samples collected from boreholes, 64 samples have arsenic in their concentrations greater than $10 \mu \mathrm{g} / \mathrm{L}$, from which 30 samples have a concentration greater than $50 \mu \mathrm{g} / \mathrm{L}$ with a maximum concentration of $176.56 \mu \mathrm{g} / \mathrm{L}$. Pollution mostly occurs in the groundwater located in the central part of the valley characterized by alluvial plains and young aquifer. Around $57 \%$ of the polluted samples have origin from deep groundwater with a depth greater than $40 \mathrm{~m}$. Reductive environment, high $\mathrm{Fe}, \mathrm{Mn}, \mathrm{HCO}_{3}$ as well as low $\mathrm{SO}_{4}{ }^{2-}$ and $\mathrm{NO}_{3}{ }_{3}^{-}$content in polluted samples suggests that reductive dissolution is a major mechanism by which arsenic is released into the groundwater. Highly polluted samples are characterized with high concentrations of $\mathrm{Mn}$ and Fe. Other investigated ions are presented in low concentrations. One factorial ANOVA showed significant differences between the As concentrations in shallow and deep groundwater. Multivariate factor analysis was performed to identify the covariance structure between the investigated variables. Arsenic was positively correlated with $\mathrm{HCO}_{3}$ and $\mathrm{Mn}$ in shallow groundwater and with $\mathrm{HCO}_{3}$, $\mathrm{Ca}$, and $\mathrm{Mn}$ in deep groundwater suggesting that arsenic is mobilized in groundwater by reductive dissolution of $\mathrm{Mn}$ oxides from the bedrock.
\end{abstract}

Keywords: arsenic, shallow groundwater, deep groundwater, reductive dissolution

\section{INTRODUCTION}

Groundwater is a major source of irrigation in the world. If arsenic polluted groundwater is used for irrigation, serious problems may occur in agriculture production. Permanent irrigation of soil with arsenic polluted water may contribute to the accumulation of this toxic element in the topsoil or subsoil and after some time render the soil unfit for agriculture production (Bhattacharya et al., 2002). According to Jiang and Singh (1994), agricultural inputs like pesticides and fertilizers may also increase the concentration of arsenic in topsoil while environmental and climate conditions may contribute to its leaching into the groundwater. Plants can accumulate some amount from the soil or the contaminated irrigation water. The quantity of the accumulated As depends on plant variety and the contamination level. Arsenic is a phytotoxic element which may cause chlorosis, yield decrease, and stunt of the plant growth. Plants usually accumulate arsenic in roots and shoots, but some plants like rice, lettuce, carrot, and potatoes are capable to accumulate As in the edible parts of the plant making it unsuitable for human consumption or other intended use (Kabata-Pendias A. and Mukherjee B. A., 2007). The pollution of groundwater with arsenic has become a global concern problem. Polluted groundwater has been found in many parts of the world in different hydrogeological and geochemical conditions. Literature data show that majority of the arsenic polluted groundwater provinces are in young unconsolidated sediments, usually from 
Quaternary or Holocene age in arid or semiarid settings (Rosas et al., 1999; Smedley et al., 2002), or in large alluvial deltaic plains (Berg et al., 2001; Smedley et al., 2005; Polya et al., 2005). This, heavy metalloid and oxyanion-forming element can reach the groundwater from natural sources like mineralization and geothermal activity or human activities like mining, industry, and the use of arsenical pesticides in agriculture and forest preservation. Arsenic pollution of groundwater which is related to mineralization and mining activities are localized in recognized regions and have been reported worldwide like the USA (Twarakawi N.K.C. and Kaluarachchi J.J., 2006) Canada (Bernard D.W., 1983; Grantham D.A. and Jones J.F., 1977), Africa (Smedley et al., 2007), Greece (Komnitsas K. et al., 1995), India (Chakraborti D. et al., 1999; Pandey P.K. et al., 2002), Mexico (Armienta M.A. et al., 2005), Thailand (Williams M., 1996), England (Thornton I., 1994), etc. Arsenic polluted groundwater associated with geothermal fluids has been reported in the USA (Wilkie J.A. and Hering J.G., 1998; Welch A.H. et al., 2000), Japan (Swedlund P.J. and Webster J.G., 1998), and New Zeland
(Robinson B. et al., 1995). Data related to arsenic contamination of groundwater associated with pesticide applications are limited and until now have been reported only in the United States (Bednar AJ., 2002; Cai Y. et al., 2002 and Wiegand GE., 1999). In the Republic of Macedonia arsenic polluted groundwater has been found in Pelagonia valley the region of Prilep (max. $75 \mu \mathrm{g} / \mathrm{L}$ ) (Mirčovski V. et al., 2014), and the region of Strumica (max. $117.875 \mu \mathrm{g} / \mathrm{L}$ ) (Ivanova Š. and Ambarkova V., 2015). According to Ravenscroft et al. (2009), there are four mobilization mechanisms of arsenic in nature: reductive dissolution (RD), alkali desorption (AD), sulphide oxidation (SO), and geothermal (GT). The purpose of this study was to make an assessment of arsenic pollution origin in groundwater which is used for irrigation and situated under intensive agriculture activities using chemometric methods like single factorial analysis of variance and multivariant factor analysis.

\section{MATERIAL AND METHODS}

\section{Investigated area}

The investigation was conducted in the Strumica valley, located in the south-eastern part of North Macedonia, approximately 15 $\mathrm{km}$ to the west of the border with Bulgaria. The groundwater of the investigated area belongs to the transboundary Petrich valley aquifer shared by the Republic of North Macedonia and Bulgaria and it is hydraulically linked with the surface water of the Struma/Strymonas river basin (Fig.1). The Aquifer is made up of Pliocene, predominantly, and Quaternary Lake sediments, alluvial sands, gravels, clays, and sandy clays (UNECE 2011). The Strumica river is a transboundary tributary to the Struma/ Strymonas river which source is in western Bulgaria (Vitosha Mountain, south of Sofia) and ends in the Aegean Sea (Strymonikos Gulf Greece) (Fig. 1). The discovered thickness of the basal lithozone ranges from 20-50 m (Rakicevik et al., 1973). The region is characterized by an intensive agriculture production since the 1950's when cotton was the main cultivated crop for the existence of domestic growers.
The construction of the irrigation systems Turia and Vodocha in 1979, contribute to the replacement of cotton production with early vegetable production which contributes to the development of the food cane industry. The region is reached in hydro geothermal water which according to Gorgieva etal. (2000) belongs in the hydrothermal systems in the fractured granites of Paleozoic or Mesozoic age. Springs and boreholes with different temperatures are present within small distances in the village of Bansko. The maximum measured temperature is $73^{\circ} \mathrm{C}$ and the predicted maximum temperature is $120^{\circ} \mathrm{C}$ (Gorgieva, 1989). The reservoir in the granites lies under thick Tertiary sediments. An abundant mine with copper and gold deposits is present in the village of llovitca located in a northwest-southeast striking Tertiary magmatic arc, that covers large areas of Macedonia, Serbia, Central Romania, Southern Bulgaria, Northern Greece, and Eastern Turkey (Carter S., 2008). 


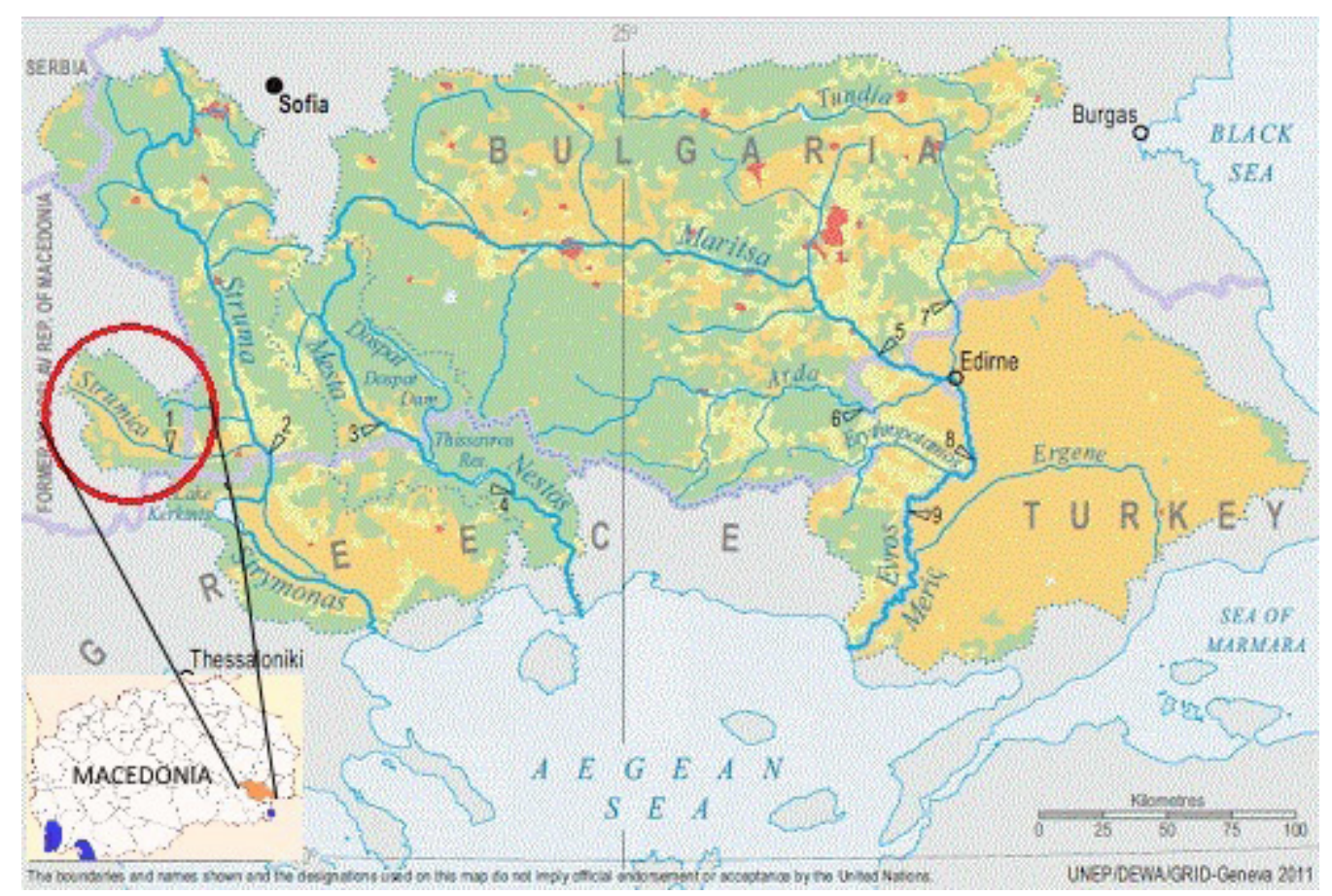

Figure 1. Geographic location of the investigated region, the Strumica valley.

\section{Chemical analysis}

Each sample was collected from a borehole located in the field of agricultural production, according to EPA guidelines (Johnston, 2007) and analysed for the quantity of major cations, anions, heavy metals, and trace elements. Anions like chlorine, carbonate, and bicarbonate were analysed by volumetric methods. Sulphate $\left(\mathrm{SO}_{4}{ }^{2-}\right)$, nitrate $\left(\mathrm{NO}_{3}{ }^{-}\right)$, nitrite $\left(\mathrm{NO}_{2}{ }^{-}\right)$, and ammonia $\left(\mathrm{NH}_{4}^{+}\right)$were determined by the colorimetric method using spectrophotometer type JENWAY 6715, UVVis (EPA 375.4; EPA 352.1; EPA 354.1; EPA 350.2). $\mathrm{pH}$ is measured by $\mathrm{pH}$ meter HANNA HI 2211-01 and electrical conductivity is measured with conductometer JENWAY 4520, in situ. The total oxidation state of arsenic (As), magnesium $(\mathrm{Mg})$, sodium $(\mathrm{Na})$, potassium $(\mathrm{K})$, calcium $(\mathrm{Ca})$, phosphorus $(\mathrm{P})$, manganese $(\mathrm{Mn})$, copper $(\mathrm{Cu})$, nickel ( $\mathrm{Ni})$, cobalt $(\mathrm{Co})$, iron ( $\mathrm{Fe})$, zinc $(\mathrm{Zn})$ and lead $(\mathrm{Pb})$ were analysed by inductively coupled plasma-mass spectrometry (ICP-MS), (Agilent 7500 CX). The equipment was linearly calibrated from 1 to $100 \mu \mathrm{g} / \mathrm{L}$, using a certified standard solution (Sigma ICP Multielement Standard
Solution). Linearity was checked after every 10 samples. Accuracy has been tested by analysing a certified reference material, NIST SRM 1643 c "Trace elements in water." Bias ranged from 2 to $7 \%$. Precision expressed as intermediate precision was better than $10 \%$ for all analysed elements.

\section{Statistical analysis}

Descriptive statistics analysis was used to perform analysis of data, including mean, median, maximum and minimums, standard deviation, and variance. One factorial ANOVA in excel was performed to see if there are significant differences of As concentrations in shallow and deep groundwater. Groundwater composition was subject to a factor analysis to understand the covariance structure between As and other variables. Varimax normalized type of rotation and multiple $\mathrm{R}$ - square methods were used for the extraction of the loadings. Descriptive and factor analysis are performed in the statistical program Statistica version 10 (StatSoft Inc., 2011). 


\section{RESULTS AND DISCUSSION}

\section{Chemical and physical characteristics of groundwater}

A total number of 185 groundwater samples have been analysed for their quality and heavy metal content (Tab. 1). The depth of the investigated boreholes ranged between 4.5 and $130 \mathrm{~m}$ with a median of $21 \mathrm{~m}$. The analytical results show that the $\mathrm{pH}$ values of groundwater samples varied between 6.84 and 8.67 with a median of 7.83 , which indicates that waters are generally slightly alkaline. The electrical conductivity of groundwater varies between 1.22 and $17.49 \mathrm{dS} / \mathrm{m}$ at $25^{\circ} \mathrm{C}$ with a median value of $4.74 \mathrm{dS} / \mathrm{m}$. According to Sawyer N.G and Mc Cartly D.L. (1967), the total hardness expressed as mass of $\mathrm{CaCO}_{3}$ ranged between $0.03-915.07$ $\mathrm{mg} / \mathrm{L}$. Around $32 \%$ of groundwater samples belong in the very hard category, $25 \%$ in the hard category, $28 \%$ belong in the moderately hard category and $25 \%$ were characterized in soft category. All heavy metals and trace elements except As, Mn, and Fe are found below the national MCL (Maximum Concentration Limits).
Almost 35\% of investigated samples have total arsenic content greater than $10 \mu \mathrm{g} / \mathrm{l}$, from which $16 \%$ have concentrations greater than 50 $\mu \mathrm{g} / \mathrm{L}$ with a maximum concentration of 176.56 $\mu \mathrm{g} / \mathrm{L}$. The most polluted were samples from the village of Robovo (eight out of nine investigated samples) with a concentration range from 65.23 - $176.56 \mu \mathrm{g} / \mathrm{L}$, then samples from the village of Sachevo where seventeen out of nineteen investigated boreholes exceeded the level of $10 \mu \mathrm{g} / \mathrm{l}$, with the concentration range from 23.31 to $172.42 \mu \mathrm{g} / \mathrm{L}$. In the village of Ednokukjevo, thirteen out of eighteen samples (range $10.37-109.46 \mu \mathrm{g} / \mathrm{L}$ ) and in the village of Borievo eleven out of twelve investigated samples were polluted $(11.54-80.42 \mu \mathrm{g} / \mathrm{L})$ with a concentration greater than $10 \mu \mathrm{g} / \mathrm{l}$. Arsenic polluted groundwater was sampled mostly from the boreholes located in the central part of the valley characterized by alluvial plains and young aquifer.

Table 1. Statistic summary of concentrations of chemical variables resulting from the descriptive analysis of investigated samples

\begin{tabular}{|c|c|c|c|c|c|c|}
\hline & Min & Max & Mean & Median & SD & CV \\
\hline $\mathbf{d}(m)$ & 4.50 & 130 & 40.2 & 21.00 & 34.32 & 85.36 \\
\hline pH & 6.84 & 8.67 & 7.85 & 7.83 & 0.45 & 5.67 \\
\hline ECw $(d S / m)$ & 1.22 & 17.49 & 4.88 & 4.74 & 2.46 & 50.41 \\
\hline $\mathrm{HCO}_{3}^{-}(\mathrm{mg} / \mathrm{L})$ & 0.04 & 750.97 & 269.65 & 265.25 & 156.61 & 58.08 \\
\hline $\mathrm{Cl}^{-}(\mathrm{mg} / \mathrm{L})$ & 4.19 & 614.31 & 39.59 & 25.13 & 55.77 & 140.88 \\
\hline $\mathrm{NO}_{3}^{-}(\mathrm{mg} / \mathrm{L})$ & 0.14 & 284.44 & 23.30 & 2.98 & 45.50 & 195.27 \\
\hline $\mathrm{NO}^{-}(\mathrm{mg} / \mathrm{L})$ & $<L O D$ & 35.85 & 0.73 & 0.025 & 3.99 & 546.69 \\
\hline $\mathbf{N H}_{4}{ }^{+}(m g / L)$ & $\angle L O D$ & 55.89 & 1.12 & 0.09 & 5.01 & 448.86 \\
\hline $\mathbf{S O}_{4}{ }^{2-}(\mathrm{mg} / \mathrm{L})$ & $\angle L O D$ & 300.45 & 24.97 & 17.57 & 37.73 & 151.06 \\
\hline $\mathrm{Na}(\mathrm{mg} / \mathrm{L})$ & 1.4 & 36.71 & 7.06 & 5.95 & 5.07 & 71.84 \\
\hline $\mathrm{PO}_{4}{ }^{3-}(\mathrm{mg} / \mathrm{L})$ & $<L O D$ & 7.8 & 0.54 & 0.19 & 1.1 & 202.62 \\
\hline $\mathbf{K}(\boldsymbol{\mu} \mathbf{g} / \mathbf{L})$ & 1.15 & 354.44 & 12.06 & 5.38 & 2.35 & 16.58 \\
\hline $\mathbf{C a}(m g / L)$ & 7.43 & 411.18 & 51.10 & 39.84 & 39.61 & 77.52 \\
\hline $\mathbf{M g}(\mathrm{mg} / \mathrm{L})$ & 1.07 & 96.14 & 13.55 & 9.77 & 12.51 & 92.33 \\
\hline As $(\mu \mathrm{g} / \mathrm{L})$ & 0.08 & 176.56 & 21.58 & 2.60 & 38.51 & 178.45 \\
\hline$M n(\mu g / L)$ & $\angle \mathrm{LOD}$ & 3328.88 & 465.10 & 288.55 & 606.78 & 130.46 \\
\hline $\mathrm{Fe}(\boldsymbol{\mu} \mathbf{g} / \mathbf{L})$ & $<L O D$ & 3165.71 & 212.29 & 71.69 & 386.89 & 182.25 \\
\hline $\mathrm{Ni}(\mu \mathrm{g} / \mathrm{L})$ & 0.32 & 21.58 & 3.36 & 2.59 & 2.67 & 79.49 \\
\hline $\mathrm{Cu}(\mu \mathrm{g} / \mathrm{L})$ & $\angle L O D$ & 21.55 & 1.35 & 1.04 & 1.74 & 128.66 \\
\hline $\mathrm{Zn}(\boldsymbol{\mu g} / \mathrm{L})$ & 2.34 & 1371.41 & 49.79 & 14.22 & 160.16 & 321.67 \\
\hline $\mathrm{Pb}(\boldsymbol{\mu g} / \mathrm{L})$ & 0.06 & 16.35 & 0.92 & 0.47 & 1.66 & 181.78 \\
\hline Co $(\mu \mathrm{g} / \mathrm{L})$ & 0.25 & 2.1 & 0.39 & 0.25 & 0.36 & 91.62 \\
\hline
\end{tabular}


Most of the arsenic polluted samples (42 samples) have depth between 21-100 m. Only fifteen samples have depth not greater than $20 \mathrm{~m}$ and 7 samples have a depth between $100-125 \mathrm{~m}$. The contaminated groundwater is mostly alkaline ( $\mathrm{pH}$ between $7.5-8.53)$, with a high concentration of bicarbonate $\left(\mathrm{HCO}_{3}-\right.$ 177.06 - 511.87) and moderate conductivity (ECW 2.48 - 7.2) (Tab. 2). Arsenic bearing rocks like calcite forms of limestone, iron oxide minerals, and sodium feldspars are common for the investigated region (Rakicevik and Pendzerkoski 1973). Groundwater from the boreholes in the village of Bansko, an area rich in geothermal springs, shows no significant content of arsenic in groundwater. The most important geothermal spring in this region has an arsenic concentration of 22.52 $\mu \mathrm{g} / \mathrm{L}$, suggesting that arsenic presence in groundwater in the region have no geothermal origin. Reducing environment present in the groundwater of the investigated area, high $\mathrm{Fe}$, $\mathrm{Mg}, \mathrm{HCO}_{3}$ as well as low $\mathrm{SO}_{4}$ and $\mathrm{NO}_{3}$ content suggests that reductive dissolution is a major mechanism by which arsenic is released into the groundwater.

Table 2. Statistic summary of concentrations of chemical variables resulting from the descriptive analysis of arsenic polluted samples

\begin{tabular}{|c|c|c|c|c|c|c|}
\hline & Min & Max & Mean & Median & SD & CV \\
\hline $\mathbf{d}(\mathrm{m})$ & 17.00 & 125.0 & 64.77 & 76.50 & 38.38 & 59.26 \\
\hline pH & 7.50 & 8.53 & 8.02 & 8.035 & 0.34 & 4.22 \\
\hline $\mathbf{E C W}(d S / m)$ & 2.48 & 7.20 & 4.95 & 4.98 & 1.17 & 23.65 \\
\hline $\mathrm{HCO}_{3}^{-}(\mathrm{mg} / \mathrm{L})$ & 177.06 & 511.87 & 359.23 & 385.45 & 92.34 & 25.70 \\
\hline $\mathrm{Cl}^{-}(m g / L)$ & 6.28 & 49.53 & 15.89 & 11.09 & 11.67 & 73.45 \\
\hline $\mathrm{NO}_{3}^{-}(\mathrm{mg} / \mathrm{L})$ & 0.65 & 19.81 & 3.77 & 1.60 & 5.33 & 141.27 \\
\hline $\mathrm{NO}_{-}^{-}(\mathrm{mg} / \mathrm{L})$ & $<$ LOD & 0.120 & 0.03 & 0.03 & 0.02 & 63.23 \\
\hline $\mathbf{N H}_{4}{ }^{+}(\mathrm{mg} / \mathrm{L})$ & $<$ LOD & 17.930 & 1.51 & 0.39 & 3.39 & 224.34 \\
\hline $\mathbf{S O}_{4}{ }^{2-}(\mathrm{mg} / \mathrm{L})$ & 0.77 & 25.760 & 7.06 & 2.50 & 7.91 & 112.01 \\
\hline $\mathrm{Na}^{+}(m g / L)$ & 1.66 & 18.350 & 8.39 & 7.45 & 3.61 & 42.98 \\
\hline $\mathrm{PO}_{4}{ }^{3-}(\mathrm{mg} / \mathrm{L})$ & $<$ LOD & 7.80 & 1.09 & 0.23 & 1.87 & 172.32 \\
\hline $\mathbf{K}(m g / L)$ & 1.23 & 10.26 & 4.83 & 4.84 & 2.59 & 53.59 \\
\hline $\mathbf{C a}(\mathrm{mg} / \mathrm{L})$ & 12.71 & 70.97 & 41.40 & 37.44 & 16.22 & 39.18 \\
\hline $\mathbf{M g}(\mathrm{mg} / \mathrm{L})$ & 3.39 & 42.33 & 9.30 & 6.51 & 9.26 & 99.63 \\
\hline As ( $\mu \mathrm{g} / \mathrm{L})$ & 50.04 & 176.56 & 101.93 & 90.60 & 38.61 & 37.88 \\
\hline$M n(\mu g / L)$ & 68.42 & 2175.17 & 692.13 & 592.86 & 498.72 & 72.06 \\
\hline $\mathrm{Fe}(\mu \mathrm{g} / \mathrm{L})$ & 28.01 & 1048.61 & 258.33 & 112.52 & 270.58 & 104.74 \\
\hline $\mathrm{Ni}(\mu \mathrm{g} / \mathrm{L})$ & 0.54 & 8.99 & 2.64 & 1.70 & 2.49 & 94.17 \\
\hline $\mathrm{Cu}(\mu \mathrm{g} / \mathrm{L})$ & $<$ LOD & 4.25 & 0.86 & 0.38 & 1.00 & 115.7 \\
\hline $\mathrm{Zn}(\boldsymbol{\mu g} / \mathrm{L})$ & 2.90 & 88.73 & 21.73 & 12.1 & 22.04 & 101.43 \\
\hline $\mathrm{Pb}(\mu \mathrm{g} / \mathrm{L})$ & $<$ LOD & 16.35 & 1.16 & 0.25 & 3.04 & 261.92 \\
\hline Co $(\mu \mathrm{g} / \mathrm{L})$ & $<\mathrm{LOD}$ & 0.70 & 0.30 & 0.25 & 0.12 & 40.24 \\
\hline
\end{tabular}

Highly polluted samples with arsenic concentration greater than $50 \mu \mathrm{g} / \mathrm{L}$ are characterized with low content of sulphate $(0.77-25.76 \mu \mathrm{g} / \mathrm{L})$, phosphate $(0.025-7.8$ $\mu \mathrm{g} / \mathrm{L})$, potassium $(1.23-10.48 \mu \mathrm{g} / \mathrm{L})$, calcium (12.71 - $75.48 \mu \mathrm{g} / \mathrm{L})$, magnesium (3.39 - 42.33 $\mu \mathrm{g} / \mathrm{L})$, nickel $(0.54-8.99 \mu \mathrm{g} / \mathrm{L})$, cuprum $(0.25-$ $4.25 \mu \mathrm{g} / \mathrm{L})$, zinc $(2.91-88.73 \mu \mathrm{g} / \mathrm{L})$, lead $(0.25$ - $16.35 \mu \mathrm{g} / \mathrm{L})$ and cobalt $(0.25-0.7 \mu \mathrm{g} / \mathrm{L})$. Concentrations of iron $(28.01-3165.71 \mu \mathrm{g} / \mathrm{L})$ and manganese $(68.42-2175.17 \mu \mathrm{g} / \mathrm{L})$ showed higher values than in unpolluted samples.

\section{Statistical analysis}

One factorial ANOVA

Single-factor ANOVA was performed to investigate if there are significant differences between As concentrations in shallow groundwater with depth up to $40 \mathrm{~m}$ and deep groundwater with a depth greater than $40 \mathrm{~m}$. For that purpose, the obtained values for As concentrations were previously normalized using Box-Cox transformation. The analysis showed that $F(37.97)$ is higher than $F$ critical (3.89) and $p$-value $\left(4.17 \mathrm{E}^{-9}\right)$ is much lower than 0.05 which indicates that there is a significant 
difference between shallow groundwater and deep groundwater regarding As concentration. The mean values of As concentrations 15.86 ppm and 34.05 ppm for shallow and deep groundwater respectively, indicate that higher concentrations are present in deep groundwater suggesting its natural origin.

Table 3. Single factor ANOVA for As concentrations in shallow and deep groundwater

\begin{tabular}{|l|cccccc|}
\hline \multicolumn{1}{|c|}{ Source of Variation } & SS & $d f$ & MS & $F$ & P-value & Fcrit \\
Between Groups & 93.83 & 1 & 93.83 & 37.97 & $4.17 \mathrm{E}-09$ & 3.89 \\
Within Groups & 472 & 191 & 2.47 & & & \\
Total & 565.83 & 192 & & & & \\
\hline
\end{tabular}

\section{Factor analysis}

Factor analysis performed for all groundwater samples revealed two factors with eigenvalues greater than one which explains only $29.96 \%$ of the total variance and $44.35 \%$ of communalities leaving too many residuals (unexplained sums of squares) (Table 4). Due to the information from this analysis, it was not possible to give a logical explanation of the association of variables. It is assumed that this outcome due to different chemical processes dominated in shallow and deep groundwater. The composition of shallow groundwater is more prone to the processes of sorption and desorption as a result of clay and organic matter content in the topsoil and subsoil. The composition of deeper groundwater is more prone to the processes related with the aquifer composition. To lower the percent of residuals, and to obtain more clear associations, factor analysis was performed separately for shallow and deep groundwater. Factor analysis for shallow groundwater revealed four factors with eigenvalues greater than one which explain $43.64 \%$ of the total variance and $50.19 \%$ of communalities (Table 5). The analysis positively associates As with $\mathrm{HCO} 3-$ and $\mathrm{Mn}$ suggesting that arsenic is mobilized in groundwater by reductive dissolution of $\mathrm{Mn}$ oxides from the bedrock. Factor analysis for deep groundwater revealed five factors with eigenvalues greater than one. Arsenic was positively associated with $\mathrm{HCO}_{-}-\mathrm{Ca}$, and $\mathrm{Mn}$ in the third factor which explains $10 \%$ of the total variance (Table 6). The obtained result is in accordance with the association obtained from the analysis of shallow groundwater, which is difficult to conclude based on the analysis when shallow and deep groundwater were statistically processed together.

Table 4. Factor analysis for all investigated samples

\begin{tabular}{|l|l|l|l|}
\hline & F1 & F2 & Comm \\
\hline $\mathrm{HCO}_{3}^{-}$ & -0.15 & $\mathbf{0 . 7 6}$ & 70.34 \\
\hline $\mathrm{Cl}^{-}$ & $\mathbf{0 . 6 8}$ & $\mathbf{0 . 5 5}$ & 85.64 \\
\hline $\mathrm{NO}_{3}^{-}$ & $\mathbf{0 . 5 6}$ & -0.01 & 47.48 \\
\hline $\mathrm{SO}_{4}^{2-}$ & $\mathbf{0 . 6 7}$ & 0.27 & 64.97 \\
\hline $\mathrm{Na}$ & 0.11 & 0.04 & 29.39 \\
\hline $\mathrm{PO}_{4}^{3-}$ & -0.16 & -0.06 & 17.88 \\
\hline $\mathrm{K}$ & 0.29 & 0.10 & 45.74 \\
\hline $\mathrm{Ca}$ & $\mathbf{0 . 6 1}$ & $\mathbf{0 . 6 5}$ & 88.76 \\
\hline $\mathrm{Mg}$ & 0.45 & $\mathbf{0 . 5 0}$ & 67.71 \\
\hline $\mathrm{As}$ & -0.49 & 030 & 36.04 \\
\hline $\mathrm{Mn}$ & -0.16 & $\mathbf{0 . 6 0}$ & 44.44 \\
\hline $\mathrm{Fe}$ & -0.30 & 0.12 & 15.59 \\
\hline $\mathrm{Ni}$ & 0.23 & 0.32 & 37.36 \\
\hline $\mathrm{Cu}$ & 0.19 & 0.02 & 18.74 \\
\hline $\mathrm{Zn}$ & 0.01 & 0.10 & 16.67 \\
\hline $\mathrm{Pb}$ & 0.06 & -0.00 & 10.53 \\
\hline $\mathrm{Co}$ & 0.43 & $\mathbf{0 . 5 5}$ & 56.67 \\
\hline E-value & 3.69 & 1.41 & $\mathbf{4 4 . 3 5 \%}$ \\
\hline Total variance \% & 21.68 & 8.28 & \\
\hline
\end{tabular}


Table 5. Factor analysis of investigated variables for shallow groundwater of the Strumica region

\begin{tabular}{|l|l|l|l|l|l|}
\hline & F1 & F2 & F3 & F4 & Comm \\
\hline $\mathrm{HCO}_{3}{ }^{-}$ & 0.38 & $\mathbf{0 . 6 7}$ & 0.04 & 0.01 & 71.03 \\
\hline $\mathrm{Cl}^{-}$ & $\mathbf{0 . 8 7}$ & -0.01 & -0.07 & 0.14 & 86.85 \\
\hline $\mathrm{NO}_{3}{ }^{-}$ & 0.23 & -0.27 & 0.07 & $\mathbf{0 . 6 6}$ & 55.16 \\
\hline $\mathrm{SO}_{4}{ }^{2-}$ & $\mathbf{0 . 6 9}$ & -0.21 & 0.03 & 0.15 & 67.04 \\
\hline $\mathrm{Na}$ & 0.15 & 0.05 & -0.27 & 0.28 & 29.28 \\
\hline $\mathrm{PO}_{4}{ }^{3-}$ & -0.22 & -0.05 & 0.05 & $\mathbf{0 . 5 4}$ & 31.44 \\
\hline $\mathrm{K}$ & 0.18 & 0.01 & -0.21 & 0.47 & 53.15 \\
\hline $\mathrm{Ca}$ & $\mathbf{0 . 8 4}$ & 0.11 & 0.18 & 0.24 & 90.28 \\
\hline $\mathrm{Mg}$ & $\mathbf{0 . 7 1}$ & 0.04 & -0.12 & -0.12 & 65.83 \\
\hline $\mathrm{As}$ & -0.18 & $\mathbf{0 . 6 5}$ & -0.04 & 0.02 & 43.37 \\
\hline $\mathrm{Mn}$ & 0.28 & $\mathbf{0 . 5 8}$ & 0.07 & -0.09 & 54.30 \\
\hline $\mathrm{Fe}$ & -0.09 & 0.34 & -0.00 & -0.05 & 13.41 \\
\hline $\mathrm{Ni}$ & 0.24 & 0.24 & 0.36 & 0.35 & 39.22 \\
\hline $\mathrm{Cu}$ & 0.09 & -0.08 & $\mathbf{0 . 5 9}$ & -0.03 & 35.09 \\
\hline $\mathrm{Zn}$ & 0.13 & 0.02 & $\mathbf{0 . 6 1}$ & -0.11 & 37.46 \\
\hline $\mathrm{Pb}$ & -0.06 & 0.03 & 0.25 & 0.04 & 13.36 \\
\hline $\mathrm{Co}$ & $\mathbf{0 . 7 4}$ & 0.12 & 0.12 & 0.05 & 66.92 \\
\hline E-value & 3.71 & 1.63 & 1.09 & 1.01 & $\mathbf{5 0 . 1 9 \%}$ \\
\hline TV \% & 21.85 & 9.58 & 6.40 & 5.95 & \\
\hline
\end{tabular}

Table 6. Factor analysis for investigated variables for deep groundwater of the Strumica region

\begin{tabular}{|l|l|l|l|l|l|l|}
\hline & F1 & F2 & F3 & F4 & F5 & Comm \\
\hline $\mathrm{HCO}_{3}{ }^{-}$ & -0.12 & 0.24 & $\mathbf{0 . 8 6}$ & -0.01 & -0.13 & 86.33 \\
\hline $\mathrm{Cl}^{-}$ & $\mathbf{0 . 8 4}$ & 0.15 & -0.06 & 0.19 & 0.12 & 84.43 \\
\hline $\mathrm{NO}_{3}{ }^{2-}$ & $\mathbf{0 . 5 8}$ & -0.32 & -0.11 & 0.13 & -0.26 & 71.20 \\
\hline $\mathrm{SO}_{4}^{-2}$ & 0.41 & 0.10 & 0.06 & 0.05 & $\mathbf{0 . 7 1}$ & 69.35 \\
\hline $\mathrm{Na}$ & 0.13 & 0.06 & 0.09 & 0.09 & $\mathbf{0 . 7 7}$ & 79.76 \\
\hline $\mathrm{PO}_{4}{ }^{3-}$ & -0.04 & 0.05 & 0.09 & $-\mathbf{0 . 7 5}$ & -0.07 & 57.72 \\
\hline $\mathrm{K}$ & $\mathbf{0 . 8 4}$ & 0.04 & 0.05 & -0.07 & 0.31 & 84.14 \\
\hline $\mathrm{Ca}$ & 0.40 & -0.01 & $\mathbf{0 . 8 0}$ & 0.15 & 0.12 & 85.21 \\
\hline $\mathrm{Mg}$ & 0.22 & 0.14 & 0.16 & -0.03 & -0.45 & 54.66 \\
\hline $\mathrm{As}$ & -0.23 & 0.14 & $\mathbf{0 . 5 9}$ & -0.07 & 0.03 & 53.85 \\
\hline $\mathrm{Mn}$ & -0.04 & -0.39 & $\mathbf{0 . 5 0}$ & -0.14 & -0.21 & 63.87 \\
\hline $\mathrm{Fe}$ & -0.07 & 0.01 & -0.05 & $-\mathbf{0 . 6 5}$ & -0.08 & 48.10 \\
\hline $\mathrm{Ni}$ & 0.21 & $-\mathbf{0 . 7 9}$ & -0.00 & 0.11 & -0.09 & 74.67 \\
\hline $\mathrm{Cu}$ & 0.36 & -0.37 & -0.19 & 0.23 & -0.01 & 60.74 \\
\hline $\mathrm{Zn}$ & -0.04 & -0.14 & 0.07 & 0.09 & -0.09 & 32.65 \\
\hline $\mathrm{Pb}$ & -0.10 & $-\mathbf{0 . 6 3}$ & -0.25 & -0.03 & 0.13 & 68.88 \\
\hline $\mathrm{Co}$ & -0.06 & $-\mathbf{0 . 7 5}$ & -0.05 & 0.00 & 0.03 & 65.85 \\
\hline $\mathrm{E}-\mathbf{v a l u e}$ & 3.00 & 2.56 & 1.83 & 1.44 & 1.24 & $\mathbf{6 7 . 1 4 \%}$ \\
\hline TV \% & 16.66 & 14.22 & 10.19 & 7.98 & 6.91 & \\
\hline
\end{tabular}

\section{CONCLUDING REMARKS}

The assessment of arsenic pollution of groundwater situated under the intensive agriculture activities was investigated in this study. The investigation was performed on the Macedonian part of the Petrich valley aquifer, located in the central part of the Strumica valley. Although, the region has potential for agrochemical, industrial and geothermal pollution, the investigation shows that groundwater is naturally contaminated from arsenic reach geological formations. 
The mechanism of reductive-dissolution from Mangan oxides are recognized as the main process that contributes to groundwater pollution. The obtained concentration levels of pollution show that groundwater from these contaminated boreholes could be hazardous for humans and animals and should not be considered as a potential source for drinking water. Regarding the agricultural production no significant symptoms of plant toxicity were observed in the field (unpublished data). Even though, there should be an awareness for the possible threat of As contamination in the critical points for agriculture production in the future. The investigation of soil pollution in these critical points should be priority in order to determine the impact of polluted irrigation water in the region.

\section{REFERENCES}

Arabadžiev, M.D., Stefov, V., Stafilov, V. \& Boev, B. (2001). Physico-chemical investigations of limestones from different localities in the Republic of Macedonia. Geologica Macedonica, 15-16, 35-41.

Armienta, M.A., Rodriguez, R., Cruz, O., Aguayo, A., Ceniceros, N., Villasenor, G., Ongley, L.K. \& Mango, H. (2005). Environmental behavior of arsenic in a mining zone: Zimapan, Mexico in Natural Arsenic in Groundwater: Occurrence, Remediation and Management. Taylor and Francis.

Bednar, A.J., Garbarino, J.R., Ranville, J.F., \& Wildeman, T.R. (2002). Presence of organoarsenicals used in cotton production in agricultural water and soil of the southern United States. J Agric Food Chem. 50(25), 7340-4.

Berg, M., Tran, H.C., Nguyen, T.C., Pham, H.V., Schertenleib, R. \& Giger W. (2001). Arsenic contamination of groundwater and drinking water in Vietnam: A human health threat. Environmental Science and Technology. 36, 1705 $-1711$.

Bernard, D. W. (1983). Arsenic leachate from an abandoned smelter, Delero. Ontario, Canada. Papers of the International Conference on Groundwater and Man, 2, 29-41.

Bhattacharya, P., Frisbie, S.H., Smith, E., Naidu, R., Jacks, G., \& Sarkar, B. (2002). Arsenic in the environment: A global perspective. In: Sarkar B (ed) Handbook of heavy metals in the environment. New York, Marcel Dekker.

Cai, Y., Cabrera, J.C., Georgiadis, M., \& Jayachandran, K. (2002). Assessment of arsenic mobility in the soils of some golf courses in South Florida. Sci Total Environ. 291(1-3), 12334.

Carter, S. (2008). Technical Report on the Copper Gold Resources on the llovitza Project, Macedonia, NI 43-101. Broad Oak Associates, Toronto, Canada.
Chakraborti, D., Biswas, B.K., Chowdhury, S.R. \& Rathore K.C. (1999). Arsenic groundwater contamination and sufferings of people in Rajnandgaon district, Madhya Pradesh, India. Current Science, 77, 502 - 504.

EPA (Environmental Protection Agency) Method 350.2, 1974. Nitrogen, Ammonia (Colorimetric, titrimetric, potentiometric distillation procedure). Approved for NPDES. Editorial revision 1974.

EPA (Environmental Protection Agency) Method 352.1, 1971. Nitrogen, Nitrate (Colorimetric, Brucine). Approved for NPDES and SDWA (Issued 1971).

EPA (Environmental Protection Agency) Method 354.1, 1971. Nitrogen, Nitrite (Spectrophotometric). Approved for NPDES (Issued 1971).

EPA (Environmental Protection Agency) Method 375.4, 1978. Sulfate (Turbidimetric). Approved for NPDES. Editorial revision 1978.

Gorgieva, M. (1989). Chemical geothermometers and mineral equilibria of some hot waters in Yugoslavia. Report UNU Geothermal Training Programme.

Gorgieva, M., Gorgiev, D., Popovski, K., Dimitrov, K., \& Manasov, S., (2000). Inferred section of the main (low-temperature) geothermal systems in the Republic of Macedonia. World Geothermal Congress 2000, Kyushu - Tohoku, Japan. Proceedings: 34213425.

Grantham, D.A. \& Jones, J.F. (1977). Arsenic contamination of water wells in Nova Scotia. $J$ Am Water Works Assoc, 69, 653-657.

Ivanova, Š. \& Ambarkova, V., (2015). Geochemical assessment of some natural waters from eastern and south-eastern Macedonia. Geologica Macedonica, 29(1), 5-14.

Jiang, Q.Q., \& Singh, B. R. (1994). Effect of different forms and sources of arsenic on crop 
yield and arsenic concentration. Water, Air and Soil Pollution, 74, 321-343.

Johnston, D., (2007). EPA Guidelines: Regulatorymonitoring and testing Groundwater sampling. Environmental Protection Agency. ISBN 978-1-921125-48-5.

Kabata-Pendias, A. \& Mukherjee, B. A., (2007). Trace elements from soil to human. ISpringer Berlin Heidelberg New York. SBN-10 3-540-32713-4

Komnitsas, K., Xenidis, A. \& Adam, K. (1995). Oxidation of pyrite and arsenopyrite in sulpidic spoils in Lavrion. Minerals Engineering, 40, 243 250.

Mirčovski, V., Boev, B. \& Ristevski, P. (2014). Heavy and toxic metals in the groundwater of the Prilep region from the Pelagonia valley. Geologica Macedonica, 28(1), 93-98.

Pandey, P.K., Yadav, S., Nair, S. \& Bhui, A. (2002). Arsenic contamination of the environment - A new perspective from centraleast India. Environment International, 28, 235 245.

Polya, D.A., Gault, A.G., Diebe, N., Feldman, P., Rosenboom, J.W., Gilligan, E., Fredericks, D., Milton, A.H., Sampson, M., Rowland, H.A.L., Lythgoe, P.R., Jones, J.C., Middleton, C. \& Cooke, D.A. (2005). Arsenic hazard in shallow Cambodian groundwaters. Mineralogical magazine, 69, $807-823$.

Rakicevik, T., \& Pendzerkoski, J., (1973). Descriptor for Basic geological card of SFRJ. 1:100 000, list Strumica. Geological department, Skopje 1-69. [Ma]

Ravenscroft, P., Brammer, H. \& Richards, K. (2009). Arsenic Pollution: A Global Synthesis. RGS - IBG Book Series. A John Wiley \& Sons, Ltd., Publication. ISBN: 978-1-405-18602-5.

Robinson, B., Outred, H., Brooks, R. \& Kirkman, J. (1995). The distribution and fate of arsenic in the Waikato River System, North Island, New Zeland. Chemical Speciation and Bioavailability, 7, 89- 96.

Rosas, I., Belmont, R., Armienta, A. \& Baez, A. (1999). Arsenic concentration in water, soil, milk and forage in Comarca Lagunera, Mexico. Water Air and Soil pollution. 112, 133-149.

Sawyer, N.G \& McCartly, D.L., (1967). Chemistry of sanitary engineers. 2nd edition, McGraw Hill, New York.

Smedeley, P.L., Knudsen, J. \& Maiga, D. (2007). Arsenic in groundwater from mineralized Proterozoic basement rock of Burkina Faso. Applied Geochemistry, 22, 1074 - 1092.
Smedley, P.L., \& Kinniburgh, D.G (2002). A review of the source, behavior and distribution of arsenic in natural waters. Applied Geochemistry. $17,517-568$.

Smedley, P.L., Kinniburgh, D.G., Macdonald, D.M.J., Nicolli, H.B., Barros, A.J., Tullio, J.O., Perace, J.M. \& Alonso, M.S (2005). Arsenic associations in sediments from the loess aquifers from $\mathrm{La}$ Pampa, Argentina. Applied Geochemistry, 20, $989-1016$.

StatSoft, Inc. (2011). STATISTICA (data analysis software system), version 10 .

Swedlund, P.J. \& Webster, J.G., (1998). Arsenic removal from geothermal bore waters: the effect of mono-silicic acid in Water - Rock Interaction. Arehart, G.B. and Hulston J.R. (editors). (Rotterdam: Balkema).

Thornton, I. (1994). Sources and pathways of arsenic in south-west England: health implications in Arsenic Exposure and Health. Chappell, W R, Abernathy, CO and Cothern C $\mathrm{R}$ (editors), Nortwood, England: Science and Technology Letters.

Twarakavi, N. K. C., Kaluarachchi, J. J. (2006). Arsenic in the shallow ground waters of conterminous United States: assessment, health risks, and costs for MCL compliance. Journal of American Water Resources Association 42 (2), 275-294.

Welch, A.H., Westjohn, D.B., Helsel, D.R. \& Wanty, R.B. (2000). Arsenic in groundwater of the United States: occurrence and geochemistry. Groundwater, 38, $589-604$.

Wiegand, GE. (1999). Preliminary Report: Environmental Quality Monitoring for Pesticides and Arsenic at Five Municipal Golf Courses in Miami-Dade County; Florida.

Wilkie, J.A. \& Hering, J.G. (1998). Rapid oxidation of geothermal arsenic (III) in stream waters of the eastern Sierra Nevada. Environmental Science and Tecnology, 32, 657 662.

Williams, M., Fordyce, F., Paijitprapapon, A. \& Charoenchaisiri, P. (1996). Arsenic contamination in surface drainage and groundwater in part of the southeast Asian tin belt, Nakhon Si Thammart Province, southern Thailnad. Environmental Geology, 27, 16 -33.

UNECE (2011) Second Assessment of Transboundary Rivers, Lakes and Groundwaters (2020, August 15). Economic Commission for Europe. Retrieved from http://www.unece.org. 


\title{
ЕДНОФАКТОРИЈАЛНА АНОВА ВО ПРОЦЕНКА НА КВАЛИТЕТОТ НА ПОДЗЕМНИТЕ ВОДИ ВО КРИТИЧНИ ОБЛАСТИ НА ЗАГАДУВАњЕ КОЕ ПОТЕКНУВА ОД ЗЕМЈОДЕЛСКИ АКТИВНОСТИ
}

\author{
Билјана Ковачевиќ', Саша Митрев' , Иван Боев², Наталија Маркова Руждиќ', Блажо Боев² \\ 'Земјоделски факултет, Универзитет „Гоче Делчев", ул. „Крсте Мисирков" 66, 2000, Шmun, \\ Република Северна Македонија \\ 2Факултет за природни и технички науки, Универзитет „Гоче Делчев“, ул. „Крсте Мисирков“ 6б, 2000, \\ Штип, Република Северна Македонија \\ * контакт автор: biljana.kovacevik@ugd.edu.mk
}

\begin{abstract}
Резиме
Зголемени концентрации на арсен се детектирани во подземните води на Струмичкиот регион, лоциран во југоисточниот дел на Македонија, каде што интензивно земјоделско производство е концентрирано на површина од околу 1000 km². Од вкупно 185 примероци на подземна вода собрани од различни бушотини, 64 покажаа концентрации повисоки од $10 \mu \mathrm{g} / \mathrm{l}$. Од нив, 30 примероци имаа концентрации повисоки од $50 \mu \mathrm{g} / \mathrm{L}$ со максимална концентрација од 176,56 $\mu \mathrm{g} / \mathrm{L}$. Ваквите зголемени концентрации на арсен се забележани кај примероците од подземна вода собрани од бушотини лоцирани главно во централниот дел на Струмичката Котлина кој се карактеризира со алувијални почви и млади подземни базени. Околу 57\% од загадените примероци се собрани од бушотини со длабочина поголема од $40 \mathrm{~m}$. Редуцирачката средина, високите вредности за $\mathrm{Fe}, \mathrm{Mn}, \mathrm{HCO}^{3}$, како и ниските вредности добиени за $\mathrm{SO}_{4}^{2-}$ и $\mathrm{NO}_{3}-$ сугерираат дека редуктивната дисолуција е главниот механизам на ослободување на арсенот во подземните води. Примероците каде што беа забележани повисоки концентрации на As се карактеризираат со високи концентрации на Mn и Fe. Другите испитувани јони беа присутни во ниски концентрации. Анализата со еднофакторијалната АНОВА покажа значителна разлика помеѓу концентрациите на As во плитките $(<40 \mathrm{~m})$ и длабоките (> $40 \mathrm{~m})$ примероци на подземна вода. Мултиваријантната факторна анализа покажа позитивна корелација помеѓу As, $\mathrm{HCO}^{3}$ и $\mathrm{Mn}$ во плитките примероци и $\mathrm{As}, \mathrm{HCO}_{3}{ }^{-}$, Са и $\mathrm{Mn}$ во длабоките примероци на подземна вода. Ваквиот резултат оди во прилог на заклучокот дека Аs е ослободен во подземните води со редуктивна дисолуција на оксидите на Mn кои влегуваат во составот на карпите од подземните базени.
\end{abstract}

Клучни зборови: арсен, плитка подземна вода, длабока подземна вода, редуктивна дисолуција. 